\title{
Article \\ Enhancement of Antimicrobial Activity of Alginate Films with a Low Amount of Carbon Nanofibers $(0.1 \%$ w/w)
}

\author{
Isaías Sanmartín-Santos ${ }^{1,+} \mathbb{D}$, Sofía Gandía-Llop ${ }^{2,+}$, Beatriz Salesa ${ }^{2} \mathbb{D}$, Miguel Martí ${ }^{2} \mathbb{D}$, \\ Finn Lillelund Aachmann ${ }^{3}$ iD and Ángel Serrano-Aroca $2, * \mathbb{D}$
}

1 Structural and Computational Biochemistry Lab, Centro de Investigación Traslacional San Alberto Magno, Universidad Católica de Valencia San Vicente Mártir, c/Quevedo 2, 46001 Valencia, Spain; isaias.sanmartin@ucv.es

2 Biomaterials and Bioengineering Lab, Centro de Investigación Traslacional San Alberto Magno, Universidad Católica de Valencia San Vicente Mártir, c/Guillem de Castro 94, 46001 Valencia, Spain; sofia.gandia@mail.ucv.es (S.G.-L.); beatriz.salesa@ucv.es (B.S.); miguel.marti@ucv.es (M.M.)

3 NOBIPOL, Department of Biotechnology and Food Science, NTNU Norwegian University of Science and Technology, Kjemi 4, 4-125, Gløshaugen, Sem Sælands vei 6, 7491 Trondheim, Norway; finn.l.aachmann@ntnu.no

* Correspondence: angel.serrano@ucv.es; Tel.: +34-963637412 (ext. 5256)

+ These authors contributed equally.

check for updates

Citation: Sanmartín-Santos, I.; Gandía-Llop, S.; Salesa, B.; Martí, M.; Lillelund Aachmann, F;

Serrano-Aroca, Á. Enhancement of Antimicrobial Activity of Alginate Films with a Low Amount of Carbon Nanofibers $(0.1 \% w / w)$. Appl. Sci. 2021, 11, 2311. https://doi.org/ 10.3390/app11052311

Academic Editor: Morgan Hamon

Received: 7 February 2021

Accepted: 3 March 2021

Published: 5 March 2021

Publisher's Note: MDPI stays neutral with regard to jurisdictional claims in published maps and institutional affiliations.

Copyright: (c) 2021 by the authors. Licensee MDPI, Basel, Switzerland. This article is an open access article distributed under the terms and conditions of the Creative Commons Attribution (CC BY) license (https:// creativecommons.org/licenses/by/ $4.0 /)$
Featured Application: Biodegradable composite biomaterials with antimicrobial properties.

Abstract: The World Health Organization has called for new effective and affordable alternative antimicrobial materials for the prevention and treatment of microbial infections. In this regard, calcium alginate has previously been shown to possess antiviral activity against the enveloped double-stranded DNA herpes simplex virus type 1 . However, non-enveloped viruses are more resistant to inactivation than enveloped ones. Thus, the viral inhibition capacity of calcium alginate and the effect of adding a low amount of carbon nanofibers $(0.1 \% w / w)$ were explored here against a non-enveloped double-stranded DNA virus model for the first time. The results of this study showed that neat calcium alginate films partly inactivated this type of non-enveloped virus and that including that extremely low percentage of carbon nanofibers (CNFs) significantly enhanced its antiviral activity. These calcium alginate/CNFs composite materials also showed antibacterial properties against the Gram-positive Staphylococcus aureus bacterial model and no cytotoxic effects in human keratinocyte $\mathrm{HaCaT}$ cells. Since alginate-based materials have also shown antiviral activity against four types of enveloped positive-sense single-stranded RNA viruses similar to SARS-CoV-2 in previous studies, these novel calcium alginate/carbon nanofibers composites are promising as broad-spectrum antimicrobial biomaterials for the current COVID-19 pandemic.

Keywords: carbon nanofibers; calcium alginate; antiviral activity; antibacterial activity; enveloped virus; DNA virus; Staphylococcus aureus

\section{Introduction}

Polymer hydrogels are crosslinked materials capable of absorbing and retaining high amounts of water [1,2]. A biopolymer commonly used to produce hydrogels is sodium alginate (SA) that is composed of different proportions and sequences of D-mannuronic (M) and L-guluronic acid $(\mathrm{G})$ blocks [3,4]. SA has been authorized by the US Food and Drug Administration for human biomedical applications due to its excellent properties such as biodegradability, renewability, cost-effectiveness, non-toxicity, and biocompatibility [5,6]. Thus, this polysaccharide biopolymer is used in a broad range of industrial areas such as water treatment, plastic packaging, and many other potential bioengineering fields [7-9]. This biopolymer can be cross-linked with $\mathrm{Ca}^{2+}$ cations to form hydrogels [10,11] with many physical properties that can be enhanced by adding very small amounts of carbon 
nanofibers (CNFs) [12]. CNFs are interesting carbon nanomaterials (CNMs) because they possess a lower cost than other CNMs and provide high electrical conductivity that can be used to fabricate conductive composites [13,14]. In addition, CNFs are filamentous 1D nanomaterials with excellent chemical and physical properties such as mechanical and electric performance $[15,16]$.

These alginate/CNFs composites have similar biological properties to neat calcium alginate in terms of cell adhesion and non-cytotoxicity [12]. We have recently reported for the first time that calcium alginate/CNFs composites have antibacterial properties that can be exploited to combat multidrug-resistant pathogens such as the life-threatening multidrug-resistant Staphylococcus epidermidis [17]. In the field of virology, non-enveloped viruses are more resistant to inactivation than enveloped viruses [18].

Calcium alginate-based materials have shown antiviral activity against the enveloped double-stranded DNA herpes simplex virus type 1 (HSV-1) [19]. However, calcium alginate's antiviral activity and the effect of incorporating a low amount $(0.1 \% w / w)$ of carbon nanofibers have never been studied before using a non-enveloped double-stranded DNA viral model [20]. Based on these previously published antiviral results [19], we hypothesized that calcium alginate could exhibit antiviral activity against this non-enveloped viral model. Since other carbon nanomaterials such as graphene oxide have been shown to be antiviral against DNA and RNA viruses such as the pseudorabies virus and porcine epidemic diarrhea virus [21], we also considered that incorporating this other type of carbon-based nanomaterials would enhance the antiviral action of calcium alginate. As far as we know, the antiviral activity of pure CNFs or added to calcium alginate has never been studied before.

\section{Materials and Methods}

\subsection{Materials}

Sodium alginate (Panreac AppliChem, Darmstadt, Germany) previously characterized [22] as following: Number average molecular mass $\left(\mathrm{M}_{\mathrm{n}}\right) 170.7 \pm 3.1 \mathrm{kDa}$, average molecular mass $\left(\mathrm{M}_{\mathrm{w}}\right) 379.5 \pm 9.5 \mathrm{kDa}$, and polydispersity $\left(\mathrm{M}_{\mathrm{w}} / \mathrm{M}_{\mathrm{n}}\right) 2.22 \pm 0.08$; distribution of Guluronic $(\mathrm{G})$ and Mannuronic $(\mathrm{M})$ as $\mathrm{F}_{\mathrm{G}}=0.427, \mathrm{~F}_{\mathrm{M}}=0.573, \mathrm{~F}_{\mathrm{GG}}=0.270$, $\mathrm{F}_{\mathrm{GGG}}=0.234$. Calcium chloride (anhydrous, granular, $\leq 7.0 \mathrm{~mm}, \geq 93.0 \%$, Sigma-Aldrich, Saint Louis, MO, USA) and carbon nanofibers (Ref: 13/0248, Graphenano, Yecla, Spain) were used as purchased.

\subsection{Synthesis}

Alginate nanocomposite films of approximately $0.25 \mathrm{~g}$ were prepared with a composition of $99.9 \% w / w$ of SA and $0.1 \% w / w$ of CNFs following a recently reported new engineering route to produce more homogenous alginate-based composites with enhanced physical properties [23]. CNFs/SA was mixed in $22 \mathrm{~mL}$ of distilled water by magnetic stirring for $1 \mathrm{~h}$ at room temperature $\left(26 \pm 0.5{ }^{\circ} \mathrm{C}\right)$, after which another aqueous solution containing $6 \%$ (with respect to the SA mass) of $\mathrm{CaCl}_{2}$ in $10 \mathrm{~mL}$ of distilled water was mixed with the CNFs/SA aqueous solution for 10 more minutes. Thin films were produced in Petri dishes after $24 \mathrm{~h}$ of drying at $37 \pm 0.5^{\circ} \mathrm{C}$ in an oven by solvent evaporation. The films were cross-linked by immersion in an aqueous calcium chloride solution $(2 \% \mathrm{w} / \mathrm{v})$ for $2 \mathrm{~h}$ and after rinsing with distilled water were vacuum dried at $60^{\circ} \mathrm{C} \pm 0.5^{\circ} \mathrm{C}$. The calcium alginate films without CNFs were produced by the same chemical procedure. These films will be referred to hereinafter as alginate and $\mathrm{CNFs} 0.1 \%$ films.

\subsection{Characterization}

\subsubsection{Electron Microscopy}

The CNFs were examined using high-resolution transmission electron microscopy (HR-TEM) in a JEM 2100F (JEOL, Tokyo, Japan) 200 kV electron microscope with energydisperse X-ray spectroscopy (EDS) at $20 \mathrm{kV}$. The sample preparation was performed dispersing a very small quantity of CNFs in dichloromethane in an ultrasound bath for ten 
minutes and then drying at ambient temperature before HR-TEM observation. A JEM-1010 (JEOL, Tokyo, Japan) $100 \mathrm{kV}$ transmission electron microscope (TEM) was utilized to observe the CNFs incorporated into the calcium alginate films. Ultrathin samples of calcium alginate/CNFs with $60 \mathrm{~nm}$ sections were prepared on a Leica Ultracut UC6 ultramicrotome (Leica Mikrosysteme GmbH, Wien, Austria) and a Diatome diamond knife (Diatome Ltd., Nidau, Switzerland). The specimens were placed on TEM grids (300 mesh) coated in carbon film.

\subsubsection{Cytotoxicity of the Film Extracts}

Human keratinocyte HaCaT cells were supplied by the IIS La Fe (Valencia, Spain). Calcium alginate/CNFs (sample) and calcium alginate (control) films were cut in the form of disks of $1 \mathrm{~cm}$ diameter. These disks were placed under ultraviolet light for $1 \mathrm{~h}$ on both sides before being immersed in a well with $1 \mathrm{~mL}$ of Dulbecco's Modified Eagle Medium without Fetal bovine serum. The ISO-10993-5 for biological evaluation of medical devices and the ISO-10993-12 for the sample preparation standard recommendations were followed in these tests. Incubation was performed in humidified $\mathrm{CO}_{2} /$ air $(5 / 95 \%)$ at $37^{\circ} \mathrm{C}$ for $72 \mathrm{~h}$. Cytotoxicity assays were carried out after collecting and filtering $(0.20 \mu \mathrm{m})$ the extracts of the sample (extract 1 ) and the control (extract 2 ). Cell culture was performed at a cell density of $5 \times 10^{5}$ cells / well in a $5 \% \mathrm{CO}_{2}$ humidified ambient at $37^{\circ} \mathrm{C}$ for $24 \mathrm{~h}$. The medium of each well was changed for $100 \mu \mathrm{L}$ of the extracts 1 and 2 . The medium used to produce the film extracts (non-cytotoxic) and a $1000 \mu \mathrm{M}$ zinc aqueous solution (high cytotoxic [24]) produced with zinc chloride was used at a volume also of $100 \mu \mathrm{L}$ as negative and positive control, respectively. Cell culture utilized $5 \mathrm{mg} / \mathrm{mL}$ methylthiazolydiphenyl-tetrazolium bromide (MTT) for $4 \mathrm{~h}$ in each well. Formazan crystals were dissolved in $100 \mu \mathrm{L}$ dimethyl sulfoxide at $25 \pm 1{ }^{\circ} \mathrm{C}$. The cell culture was followed by measuring the absorbance at $550 \mathrm{~nm}$ with a microplate reader (Varioskan, Thermo Fisher, Waltham, MA, USA). Cytotoxic tests were measured with six technical replicates in order to ensure reproducibility.

\subsubsection{Antibacterial Agar Disk Diffusion Tests}

The antibacterial activity of the composites was studied by the agar disk diffusion tests [22]. The disk films were sterilized in $70 \%$ ethanol and under ultraviolet radiation for $1 \mathrm{~h}$ (per each side). Lawns with a concentration of about $1.5 \times 10^{6} \mathrm{CFU} / \mathrm{mL}$ of the Gram-positive Staphylococcus aureus, V329 [25], and the Gram-negative Escherichia coli, CECT 101, in tryptic soy broth were cultivated on trypticase soy agar plates. The lawns of bacteria with the sterilized disks were incubated aerobically at $37^{\circ} \mathrm{C}$ for $24 \mathrm{~h}$. The normalized antibacterial action of each material was expressed by the normalized width of the microbial inhibition zone $\left(n w_{\text {halo }}\right)$ calculated with Equation (1) [22]:

$$
n w_{\text {halo }}=\frac{\frac{d_{i z}-d}{2}}{d}
$$

where $d_{i z}$ and $d$ are the inhibition zone diameter and film disk diameter, respectively. The Image J image software was used to measure these diameters. These antibacterial assays were performed four times on different days to provide reproducible results.

\subsubsection{Antiviral Activity Tests}

The Escherichia coli B, living bacteriophage host (Reference: 12-4300), and the coliphage T4r (Reference: 12-4335) from Carolina (Burlington, NC, USA) were used for the antiviral tests. The sample films of alginate, $\mathrm{CNFs} 0.1 \%$ were cut into $1 \mathrm{~cm}$ diameter discs and sterilized by washing the films for $30 \mathrm{~min}$ in a beaker with $50 \mathrm{~mL}$ of $70 \%$ ethanol under magnetic stirring at 450 r.p.m. The discs were then dried at room temperature and exposed to ultraviolet light for $1 \mathrm{~h}$ per side. The films' antiviral activity was analyzed by a "contact test" of the bacteriophages with the discs in 96-well plates for $10 \mathrm{~min}$, and 18 and $48 \mathrm{~h}$. The dry film disc was placed in a precision balance and drops of phosphate buffer saline (PBS) solution were added with a volumetric micropipette until the film was saturated without 
excess liquid. The correct volume for the saturation point (44 $\mu \mathrm{L}$ of liquid per disc) was determined gravimetrically by the increase in weight. For the "contact test", $44 \mu \mathrm{L}$ with approximately 700 plaque-forming units (PFU) was added to each disc, and the 24-well plate was subsequently sealed with plastic film to prevent evaporation during the assay. After each test, the wells were filled with $500 \mu \mathrm{L}$ of PBS for washing, after which the discs were extracted using sterile forceps and stored with their corresponding liquid in $15 \mathrm{~mL}$ tubes and sonicated for $5 \mathrm{~min}$. The tubes were then vortexed for $1 \mathrm{~min}$ and all the discs of the samples of contact at the different times were titrated. Six discs of each material were used to provide reproducible results at the three different contact times. The infectious phage particles were determined based on the "double layer" assay method [26]. Briefly, $500 \mu \mathrm{L}$ phage aliquots extracted from the disc were mixed with $150 \mu \mathrm{L}$ of bacterial culture and $3 \mathrm{~mL}$ of the "top agar" $(0.75 \% w / w$ agar in LB medium) preheated in a bath incubator to $45^{\circ} \mathrm{C}$. The E. coli B culture was grown overnight until reaching an optical density of 1.0 at $600 \mathrm{~nm}$. The samples were gently shaken and poured over Petri dishes with the "bottom agar" (1.5\% $w / w$ agar in LB medium). The viable PFU viral particles were calculated from the plaques appearing on the soft agar surface stained with crystal violet. Five hundred microliters of phage aliquot with approximately $700 \mathrm{PFU}$ was mixed with the bacteria and used as a control.

\subsubsection{Statistical Analysis}

The statistical analyses were performed by ANOVA followed by Tukey's posthoc test $\left.{ }^{* * *} p>0.001\right)$ on GraphPad Prism 6 software.

\section{Results and Discussion}

\subsection{Morphology, Elementary Composition}

Pure CNFs were observed by high-resolution transmission electron microscopy (HRTEM) and showed a morphology typical of these carbon materials [27] composed of irregular micrometer-length hollow fibers with a wide range of nanometric diameters (see Figure 1a). The EDS of the CNFs showed C/O ratios of 31.3. The TEM micrographs (Figure $1 \mathrm{~b}$ ) of the calcium alginate/CNFs ultrathin composite samples showed that the $\mathrm{CNFs}$ (dark phase) are embedded and heterogeneously distributed in the polar alginate polymer cross-sectional matrix (clear phase) because these carbon materials are highly hydrophobic and non-polar in nature [28].

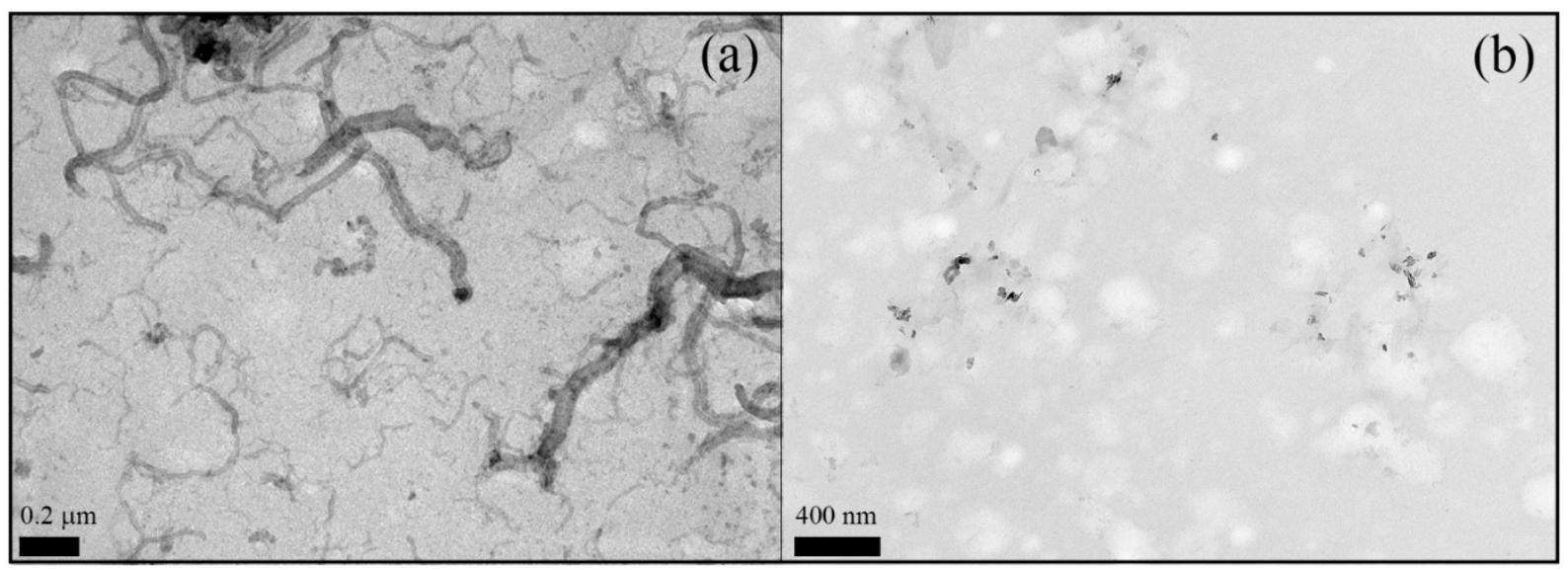

Figure 1. High-resolution (HR)-TEM of pure carbon nanofibers (a), TEM ultrathin sections of calcium alginate films with $0.1 \% w / w$ of carbon nanofibers $(\mathbf{b})$. 


\subsection{Antiviral Properties}

Figure 2 shows the plaque-forming units per $\mathrm{mL}$ measured in the antiviral tests after $10 \mathrm{~min}$, and 18 and $48 \mathrm{~h}$ of contact with bacteriophage $\mathrm{T} 4$.

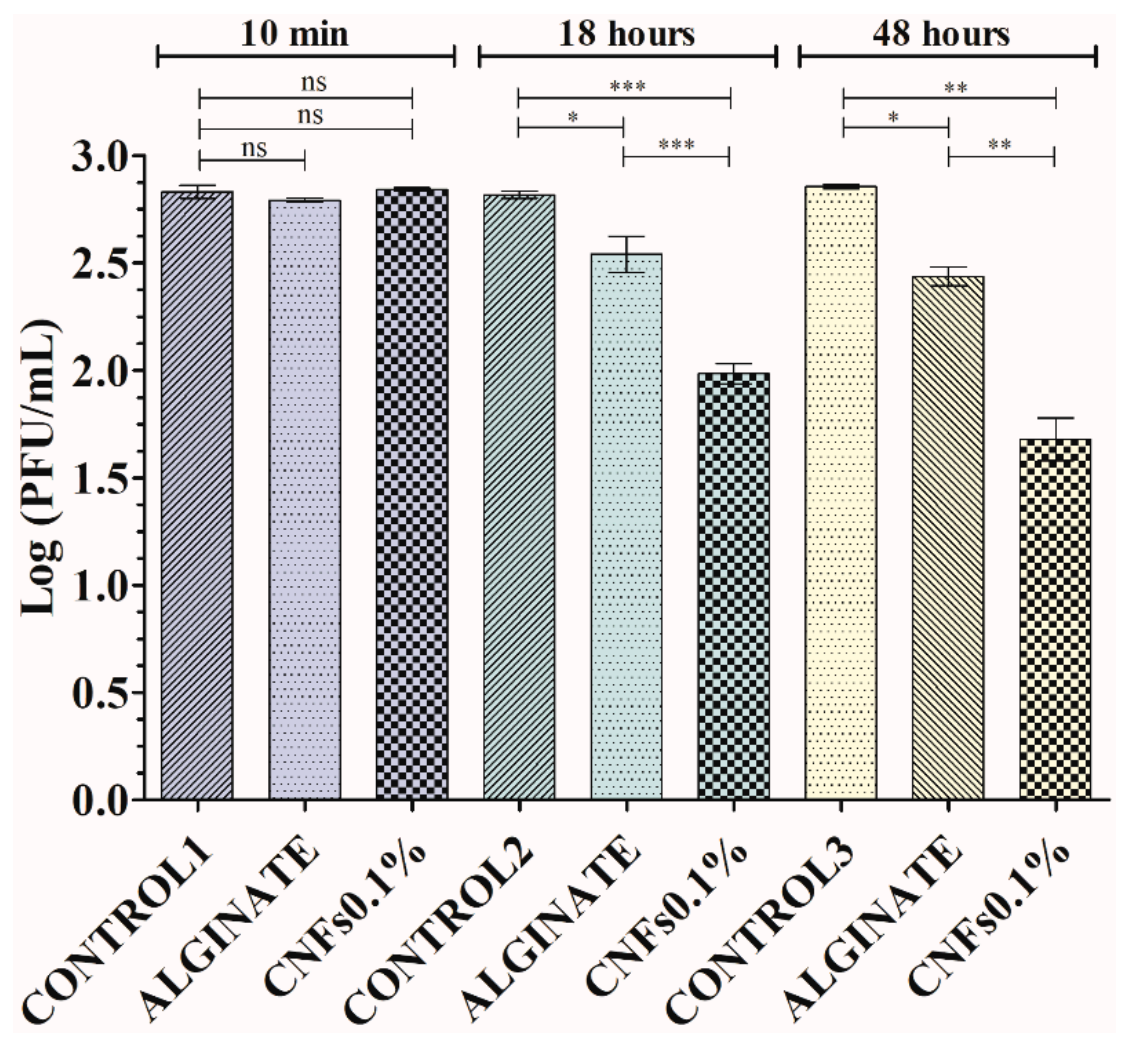

Figure 2. Antiviral activity results of control, alginate films, alginate/carbon nanofibers composite films (CNFs $0.1 \%$ ) after $10 \mathrm{~min}$, and 18 and $48 \mathrm{~h}$ of contact with the bacteriophage T4 viral model. *** $p>0.001 ;{ }^{* *} p>0.01 ;{ }^{*} p>0.05 ;$ ns: not significant.

These results showed no statistically significant antiviral activity in the samples at 10 min of contact, indicating that there is not enough time for viral inactivation. In addition, these results at a short time demonstrate that no viral inactivation is produced by the sonication-vortex treatment (see Figures 2 and 3).

However, after $18 \mathrm{~h}$ of contact with the non-enveloped double-stranded DNA T4 virus, the viable phage counts were partly significantly $(p>0.05)$ reduced in calcium alginate (see Figures 2 and 3) as reported for the enveloped double-stranded DNA HSV-1 virus [19].

Calcium alginate's antiviral action did not improve after a longer exposure period (48 h). However, the calcium alginate films with a $0.1 \%$ carbon nanofiber content achieved approximately a log of inactivation after $48 \mathrm{~h}$ (see Figures 2 and 3), showing that CNFs provide additional antiviral capacity. 


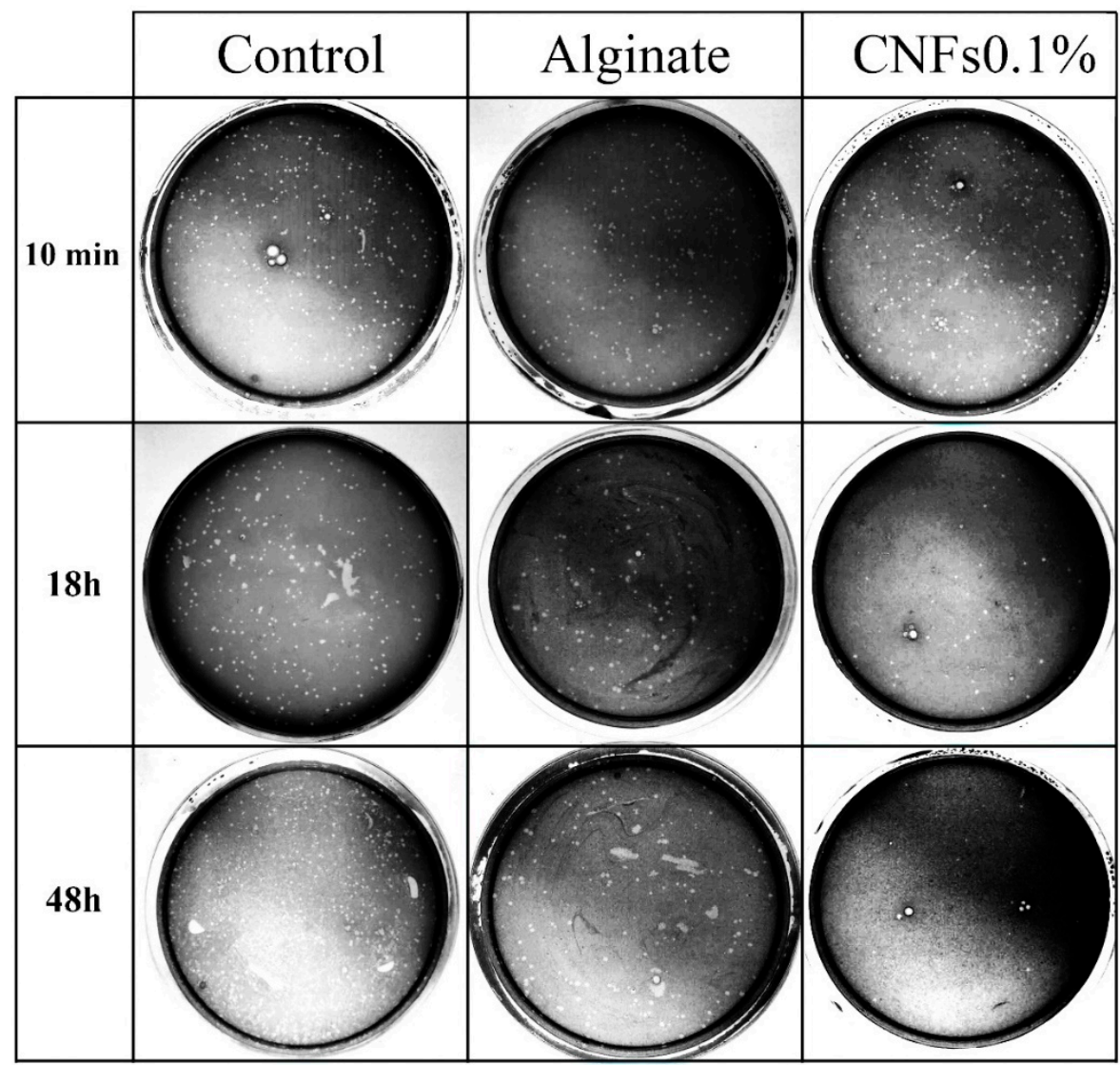

Figure 3. Representative titration plaques of bacteriophage T4: antiviral tests of alginate films and alginate/carbon nanofibers films (CNFs $0.1 \%$ ) at $10 \mathrm{~min}$, and 18 and $48 \mathrm{~h}$ of contact with the virus.

\subsection{Antibacterial Properties}

The antibacterial results of the CNFs $0.1 \%$ films against the Gram-positive and Gramnegative bacterial model are shown in Figure 4.

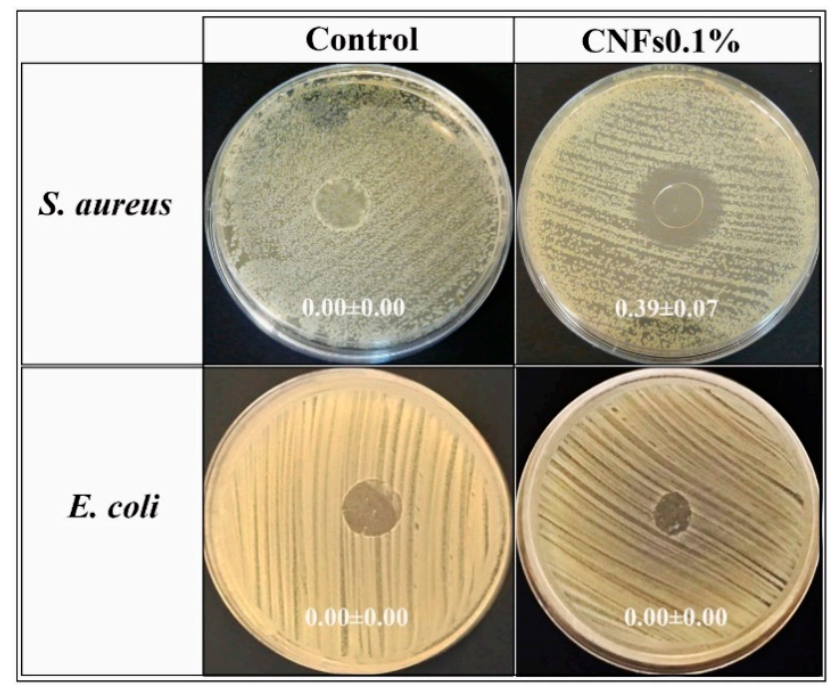

Figure 4. Antibacterial agar disk diffusion tests performed with the calcium alginate (control) film and the calcium alginate/carbon nanofibers (CNFs0.1\%) composite films against the Gram-positive Staphylococcus aureus bacterial model and the Gram-negative Escherichia coli bacterial model. The normalized antibacterial halos (mean \pm standard deviation) obtained with Equation (1) are indicated in the images. 
Even though viruses and bacteria are completely different [29], these results are in good agreement with the antiviral results shown in Figures 2 and 3, which demonstrate that these $\mathrm{CNF} 0.1 \%$ composite materials possess broad-spectrum antimicrobial activity against the non-enveloped double-stranded DNA virus and the Gram-positive S. aureus bacteria. However, these composite materials were not able to inhibit the growth of the E. coli Gramnegative bacterial model (see Figure 4), probably due to their different membrane structure which renders Gram-negative bacteria more resistant than Gram-positive bacteria [30].

\subsection{Cytotoxicity Tests}

The results of the cytotoxicity tests are shown in Figure 5.

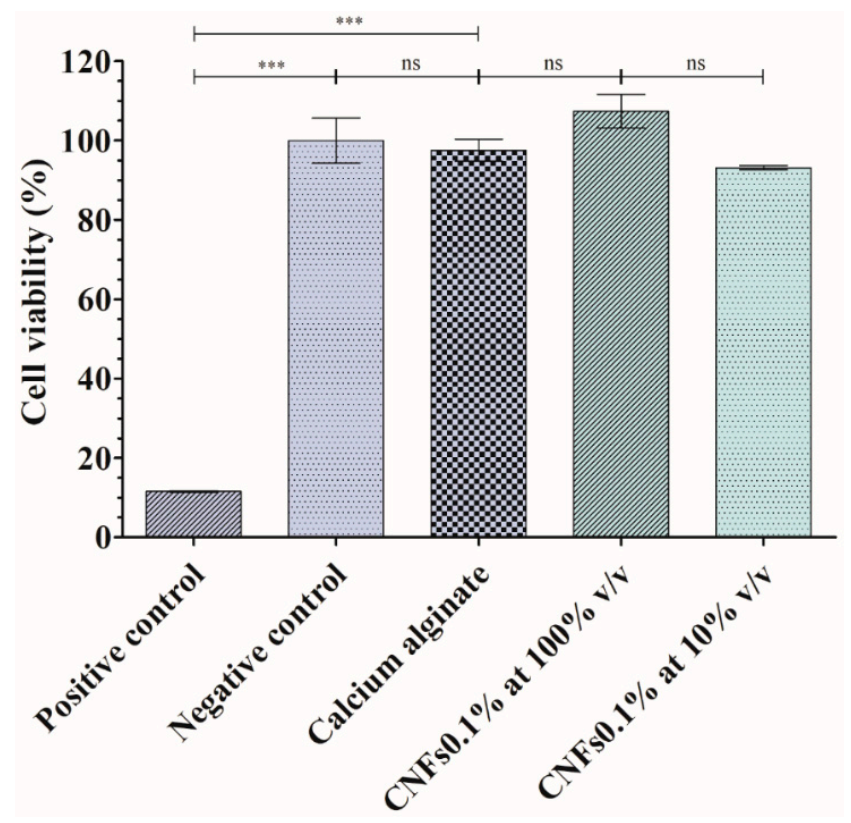

Figure 5. Cell viability (\%) of extracts of calcium alginate (at 100\% v/v) and calcium alginate/CNFs films (at 100\% and 10\% v/v), culture medium (negative control), and $1000 \mu \mathrm{M}$ zinc chloride cytotoxic solution (positive control) in human keratinocyte HaCaT cells. Only significant statistical differences were found with the negative control. ${ }^{* *} p>0.001$; ns: not significant.

No statistically significant differences were found between the cell viability of human keratinocyte $\mathrm{HaCaT}$ cells cultivated in the extract of the CNFs $0.1 \%$ composite films with respect to that of the calcium alginate or control culture medium.

These results show the first antiviral study of calcium alginate against a non-enveloped double-stranded DNA virus. The negative electric charge of this type of biopolymer is believed to be the main mechanism involved in its antiviral activity [31,32]. Thus, alginate's antiviral activity may be caused by blocking the decapsulation process of the non-enveloped virus protein on the surface of the cell membrane [33]. Here, we report also the first study of the antiviral activity of calcium alginate/CNFs composites against this type of non-enveloped virus. CNFs possess also a negatively charged surface and have a high surface/volume ratio [27,34]. Therefore, the enhancement of the antiviral activity of calcium alginate could be attributed to the increase of negative charge even with the addition of a low amount of CNFs. These results are in good accordance with those obtained with other carbon-based nanomaterials (CBNs) tested against other non-enveloped viruses such as norovirus [35], novel duck reovirus [36], and bacteriophage MS2 [37]. Nonetheless, further work is needed to study the antiviral activity of these calcium alginate/carbon nanofibers composite materials against a potentially pathogenic naked virus to validate the results obtained here for potential antiviral biomedical applications. CBNs are very promising broad-spectrum antimicrobial biomaterials because they are characterized by a low risk of microbial resistance $[29,38,39]$. Furthermore, alginate-based materials have 
shown antiviral capacity against enveloped positive-sense single-stranded RNA viruses similar to SARS-CoV-2: human immunodeficiency virus type 1, rubella virus, hepatitis C virus, and sindbis virus $[19,40,41]$. Therefore, these calcium alginate/carbon nanofibers composites are very promising for many biomedical applications in need of non-toxic materials with antiviral and antibacterial capacity for the current and future pandemics.

\section{Conclusions}

We have shown that sodium alginate films crosslinked with divalent cations of calcium possess antiviral activity against a non-enveloped double-stranded DNA virus for the first time. Furthermore, the incorporation of a low percentage of carbon nanofibers $(0.1 \%$ $w / w)$ can significantly enhance the antiviral activity of calcium alginate films. These calcium alginate/carbon nanofibers nanocomposite films showed no cytotoxicity, viral inhibition capacity, and antibacterial properties against the Gram-positive S. aureus, which render them very promising composite biomaterials for a broad range of antimicrobial biomedical applications.

Author Contributions: Conceptualization: Á.S.-A.; methodology and validation: I.S.-S., M.M. and Á.S.-A.; formal analysis: Á.S.-A.; software: Á.S.-A.; investigation: I.S.-S., S.G.-L., B.S., M.M. and Á.S.-A.; resources: Á.S.-A.; data curation: S.G.-L., B.S. and Á.S.-A.; visualization: Á.S.-A.; writingoriginal draft preparation: Á.S.-A.; writing—review and editing: I.S.-S., M.M., F.L.A. and Á.S.-A.; supervision: I.S.-S., M.M. and Á.S.-A.; project administration: Á.S.-A.; funding acquisition: Á.S.-A. All authors have read and agreed to the published version of the manuscript.

Funding: This research was funded by the Fundación Universidad Católica de Valencia San Vicente Mártir, grant 2020-231-006UCV (awarded to Á.S.-A.).

Institutional Review Board Statement: Not applicable.

Informed Consent Statement: Not applicable.

Data Availability Statement: Data are contained within the article.

Acknowledgments: The authors would like to express their gratitude to the Fundación Universidad Católica de Valencia San Vicente Mártir for their financial support.

Conflicts of Interest: The authors declare no conflict of interest.

\section{References}

1. Ahmed, E.M. Hydrogel: Preparation, characterization, and applications: A review. J. Adv. Res. 2015, 6, 105-121. [CrossRef] [PubMed]

2. Augst, A.D.; Kong, H.J.; Mooney, D.J. Alginate Hydrogels as Biomaterials. Macromol. Biosci. 2006, 6, 623-633. [CrossRef] [PubMed]

3. Kaplan, D.L. Biopolymers from Renewable Resources; Springer: Berlin/Heidelberg, Germany, 1998.

4. Vauchel, P.; Kaas, R.; Arhaliass, A.; Baron, R.; Legrand, J. A New Process for Extracting Alginates from Laminaria digitata: Reactive Extrusion. Food Bioprocess. Technol. 2008, 1, 297-300. [CrossRef]

5. Ratner, B.D.; Hoffman, A.S.; Schoen, F.J.; Lemons, J.E. Biomaterials Science: An. Introduction to Materials in Medicine; Academic Press: Toronto, ON, Canada, 2012; ISBN 008087780X.

6. Ilmi, Z.N.; Wulandari, P.A.C.; Husen, S.A.; Winarni, D.; Alamsjah, M.A.; Awang, K.; Vastano, M.; Pellis, A.; MacQuarrie, D.; Pudjiastuti, P. Characterization of Alginate from Sargassum duplicatum and the Antioxidant Effect of Alginate-Okra Fruit Extracts Combination for Wound Healing on Diabetic Mice. Appl. Sci. 2020, 10, 6082. [CrossRef]

7. Draget, K.; Bræk, G.S.; Smidsrød, O. Alginic acid gels: The effect of alginate chemical composition and molecular weight. Carbohydr. Polym. 1994, 25, 31-38. [CrossRef]

8. Zactiti, E.M.; Kieckbusch, T.G. Release of potassium sorbate from active films of sodium alginate crosslinked with calcium chloride. Packag. Technol. Sci. 2009, 22, 349-358. [CrossRef]

9. Doran, P.M. Bioprocess. Engineering Principles; Academic Press: Oxford, UK, 2013.

10. Rehm, B.H.A.; Moradali, M.F. Alginates and Their Biomedical Applications; Springer: Berlin/Heidelberg, Germany, 2018; Volume 11, ISBN 978-981-10-6909-3.

11. Aarstad, O.; Heggset, E.B.; Pedersen, I.S.; Bjørnøy, S.H.; Syverud, K.; Strand, B.L. Mechanical Properties of Composite Hydrogels of Alginate and Cellulose Nanofibrils. Polymers 2017, 9, 378. [CrossRef] 
12. Llorens-Gámez, M.; Salesa, B.; Serrano-Aroca, Á. Physical and biological properties of alginate/carbon nanofibers hydrogel films. Int. J. Biol. Macromol. 2020, 151, 499-507. [CrossRef]

13. Stout, D.A.; Basu, B.; Webster, T.J. Poly(lactic-co-glycolic acid): Carbon nanofiber composites for myocardial tissue engineering applications. Acta Biomater. 2011, 7, 3101-3112. [CrossRef]

14. Nayak, L.; Chaki, T.K.; Khastgir, D. Electrical percolation behavior and electromagnetic shielding effectiveness of polyimide nanocomposites filled with carbon nanofibers. J. Appl. Polym. Sci. 2014, 131. [CrossRef]

15. Morgan, P. Carbon Fibers and Their Composites, 1st ed.; Taylor and Francis: Boca Raton, FL, USA, 2005; ISBN 9780824709839.

16. Gardea, F.; Naraghi, M.; Lagoudas, D. Effect of Thermal Interface on Heat Flow in Carbon Nanofiber Composites. ACS Appl. Mater. Interfaces 2013, 6, 1061-1072. [CrossRef]

17. Salesa, B.; Martí, M.; Frígols, B.; Serrano-Aroca, Á. Carbon Nanofibers in Pure Form and in Calcium Alginate Composites Films: New Cost-Effective Antibacterial Biomaterials against the Life-Threatening Multidrug-Resistant Staphylococcus epidermidis. Polymers 2019, 11, 453. [CrossRef] [PubMed]

18. Blázquez, E.; Rodríguez, C.; Ródenas, J.; Navarro, N.; Riquelme, C.; Rosell, R.; Campbell, J.; Crenshaw, J.; Segalés, J.; Pujols, J.; et al. Evaluation of the effectiveness of the SurePure Turbulator ultraviolet-C irradiation equipment on inactivation of different enveloped and non-enveloped viruses inoculated in commercially collected liquid animal plasma. PLoS ONE 2019, 14, e0212332. [CrossRef]

19. Tran, N.-M.; Dufresne, M.; Helle, F.; Hoffmann, T.W.; Francois, C.; Brochot, E.; Paullier, P.; Legallais, C.; Duverlie, G.; Castelain, S. Alginate Hydrogel Protects Encapsulated Hepatic HuH-7 Cells against Hepatitis C Virus and Other Viral Infections. PLoS ONE 2014, 9, e109969. [CrossRef] [PubMed]

20. Fokine, A.; Rossmann, M.G. Molecular architecture of tailed double-stranded DNA phages. Bacteriophage 2014,4 , e28281. [CrossRef]

21. Ye, S.; Shao, K.; Li, Z.; Guo, N.; Zuo, Y.; Li, Q.; Lu, Z.; Chen, L.; He, Q.; Han, H. Antiviral Activity of Graphene Oxide: How Sharp Edged Structure and Charge Matter. ACS Appl. Mater. Interfaces 2015, 7, 21571-21579. [CrossRef]

22. Frígols, B.; Martí, M.; Salesa, B.; Hernández-Oliver, C.; Aarstad, O.A.; Ulset, A.-S.T.; Sætrom, G.I.; Aachmann, F.L.; Serrano-Aroca, Á. Graphene oxide in zinc alginate films: Antibacterial activity, cytotoxicity, zinc release, water sorption/diffusion, wettability and opacity. PLoS ONE 2019, 14, e0212819. [CrossRef]

23. Serrano-Aroca, Á.; Iskandar, L.; Deb, S. Green synthetic routes to alginate-graphene oxide composite hydrogels with enhanced physical properties for bioengineering applications. Eur. Polym. J. 2018, 103, 198-206. [CrossRef]

24. Straccia, M.C.; Romano, I.; Oliva, A.; Santagata, G.; Laurienzo, P. Crosslinker effects on functional properties of alginate/Nsuccinylchitosan based hydrogels. Carbohydr. Polym. 2014, 108, 321-330. [CrossRef] [PubMed]

25. Cucarella, C.; Solano, C.; Valle, J.; Amorena, B.; Lasa, I.; Penadés, J.R. Bap, a Staphylococcus aureus Surface Protein Involved in Biofilm Formation. J. Bacteriol. 2001, 183, 2888-2896. [CrossRef] [PubMed]

26. Kropinski, A.M.; Mazzocco, A.; Waddell, T.E.; Lingohr, E.; Johnson, R.P. Enumeration of Bacteriophages by Double Agar Overlay Plaque Assay. Methods Mol. Biol. 2009, 501, 69-76. [CrossRef] [PubMed]

27. Tshwenya, L.; Marken, F.; Arotiba, O.A. Carbon Nanofibers Provide a Cationic Rectifier Material: Specific Electrolyte Effects, Bipolar Reactivity, and Prospect for Desalination. ChemElectroChem 2019, 6, 3145-3153. [CrossRef]

28. Chaba, J.M.; Nomngongo, P.N. Preparation of V2O5-ZnO coated carbon nanofibers: Application for removal of selected antibiotics in environmental matrices. J. Water Process. Eng. 2018, 23, 50-60. [CrossRef]

29. Innocenzi, P.; Stagi, L. Carbon-based antiviral nanomaterials: Graphene, C-dots, and fullerenes. A perspective. Chem. Sci. 2020, 11, 6606-6622. [CrossRef] [PubMed]

30. Breijyeh, Z.; Jubeh, B.; Karaman, R. Resistance of Gram-Negative Bacteria to Current Antibacterial Agents and Approaches to Resolve It. Molecules 2020, 25, 1340. [CrossRef]

31. Conti, C.; Mastromarino, P.; Riccioli, A.; Orsi, N. Electrostatic interactions in the early events of VSV infection. Res. Virol. 1991, 142, 17-24. [CrossRef]

32. Pietropaolo, V.; Seganti, L.; Marchetti, M.; Sinibaldi, L.; Orsi, N.; Nicoletti, R. Effect of natural and semisynthetic polymers on rabies virus infection in CER cells. Res. Virol. 1993, 144, 151-158. [CrossRef]

33. Sano, Y. Antiviral activity of alginate against infection by tobacco mosaic virus. Carbohydr. Polym. 1999, 38, 183-186. [CrossRef]

34. Asmaly, H.A.; Abussaud, B.; Ihsanullah; Saleh, T.A.; Gupta, V.K.; Atieh, M.A. Ferric oxide nanoparticles decorated carbon nanotubes and carbon nanofibers: From synthesis to enhanced removal of phenol. J. Saudi Chem. Soc. 2015, 19, 511-520. [CrossRef]

35. Dong, X.; Moyer, M.M.; Yang, F.; Sun, Y.-P.; Yang, L. Carbon Dots' Antiviral Functions Against Noroviruses. Sci. Rep. 2017, 7, 1-10. [CrossRef]

36. Du, X.; Xiao, R.; Fu, H.; Yuan, Z.; Zhang, W.; Yin, L.; He, C.; Li, C.; Zhou, J.; Liu, G.; et al. Hypericin-loaded graphene oxide protects ducks against a novel duck reovirus. Mater. Sci. Eng. C 2019, 105, 110052. [CrossRef]

37. Badireddy, A.R.; Budarz, J.F.; Chellam, S.; Wiesner, M.R. Bacteriophage Inactivation by UV-A Illuminated Fullerenes: Role of Nanoparticle-Virus Association and Biological Targets. Environ. Sci. Technol. 2012, 46, 5963-5970. [CrossRef] [PubMed]

38. Zou, X.; Zhang, L.; Wang, Z.; Luo, Y. Mechanisms of the Antimicrobial Activities of Graphene Materials. J. Am. Chem. Soc. 2016, 138, 2064-2077. [CrossRef] [PubMed]

39. Tegou, E.; Magana, M.; Katsogridaki, A.E.; Ioannidis, A.; Raptis, V.; Jordan, S.; Chatzipanagiotou, S.; Chatzandroulis, S.; Ornelas, C.; Tegos, G.P. Terms of endearment: Bacteria meet graphene nanosurfaces. Biomaterials 2016, 89, 38-55. [CrossRef] [PubMed] 
40. Mastromarino, P.; Petruzziello, R.; Macchia, S.; Rieti, S.; Nicoletti, R.; Orsi, N. Antiviral activity of natural and semisynthetic polysaccharides on the early steps of rubella virus infection. J. Antimicrob. Chemother. 1997, 39, 339-345. [CrossRef] [PubMed]

41. Hui, B.; Li, J.; Geng, M.Y. Sulfated polymannuroguluronate, a novel anti-acquired immune deficiency syndrome drug candidate, decreased vulnerability of PC12 cells to human immunodeficiency virus tat protein through attenuating calcium overload. J. Neurosci. Res. 2008, 86, 1169-1177. [CrossRef] [PubMed] 